\title{
Sustainability strategies for PV: framework, status and needs
}

\author{
Estelle Gervais* (D), Sina Herceg, Sebastian Nold, and Karl-Anders Weiß \\ Fraunhofer Institute for Solar Energy Systems ISE, Freiburg 79110, Germany
}

Received: 30 June 2021 / Received in final form: 8 October 2021 / Accepted: 19 October 2021

\begin{abstract}
The large-scale deployment of photovoltaics (PV) is a central pillar in decarbonizing energy systems and reaching climate goals. Although PV is inherently associated to environmental awareness, it is not immune to reputational risks nor exempt of a responsibility for transparency and sustainability leadership. So far, advances in the PV industry have mainly been shaped by cost-reduction targets. We identified in previous works 16 topics where the PV sector comes short in addressing the United Nations Sustainable Development Goal 12 (SDG 12) "Ensure sustainable consumption and production patterns". In this paper, practical approaches to address each of these sustainability gaps are proposed. The best-practices identified cover all aspects of sustainability as defined by SDG 12-from resource use and hazardous substances through corporate reporting and risk assessment to due diligence and waste management. Insights on methodological needs to improve sustainability assessment and accounting in PV are also provided. The compiled list of actions needed, although not intended to be exhaustive, constitutes a starting point for stakeholders to raise their ambitions and achieve more sustainability in PV value chains.
\end{abstract}

Keywords: Photovoltaics / sustainable development goal 12 / circularity / life-cycle sustainability / roadmap

\section{Introduction}

For the past 15 years, sustainable practices associated with the production and disposal of photovoltaic (PV) modules have been a growing subject of concern. The use of critical and toxic materials [1], incidents linking PV manufacturing to chemical pollution [2] and limited waste regulation outside the EU [3] have been cited as hotspots in the sector. More recently, the allegations of forced labor in the Xinjiang Province of China, upon which the global solar industry is dependent for polysilicon, brought to public light the lack of traceability in supply chains [4]. They echoed the findings of the Business \& Human Rights Resource Centre that most renewable energy companies do not provide the necessary human rights policies to avoid the abuse of communities and workers [5]. The terawattscale deployment of solar energy, necessary to limit global warming to $1.5^{\circ} \mathrm{C}$ above pre-industrial levels [6], can aggravate the current gaps existing in the sector. Reputational risks are also not to be overlooked.

Initiatives from policymakers, industrials and researchers have emerged to improve sustainability in $\mathrm{PV}$, with a strong focus on the reduction of solar carbon footprint. The global warming potential of produced electricity, excluding balance of system (BOS), decreased

\footnotetext{
* e-mail: estelle.gervais@ise.fraunhofer.de
}

from 33-76 g CO2-eq/kWh in 2013 to 13-30 g CO2-eq/kWh in 2021, depending on production location and electricity yield calculation method [7]. Progress has been driven by improvements in production, module design and efficiency as well as guided by instruments such as Product Environmental Footprint Category Rules (PEFCR) and carbon footprint requirements in public tenders. The recycling of end-of-life modules has also gained momentum. While mechanical sorting of aluminum, copper and glass has become common practice in the EU under the Waste Electrical and Electronic Equipment (WEEE) Directive, ongoing research projects aim at recovering the smaller fractions of valuable materials, beyond a $90 \%$ recycling yield [8]. An excerpt of the PV sustainability landscape is provided in Figure 1.

Despite a wave of activities, the PV value-chain appears relatively fragmented. Sustainable practices linked to raw material procurement and panel repair/reuse are limited. Trends such as the switch from slurry-based wafering to diamond wire sawing, the continuous reduction of silver paste use and silicon kerf loss per cell [9] have admittedly shaped a more efficient use of resources. They are however primarily driven by the motivation of cost reduction: Their potential to sufficiently contribute to a sustainable manufacturing from an environmental and social point of view remains uncertain. While Life Cycle Assessment (LCA) is a well-established method for stakeholders to quantify their environmental impacts, 


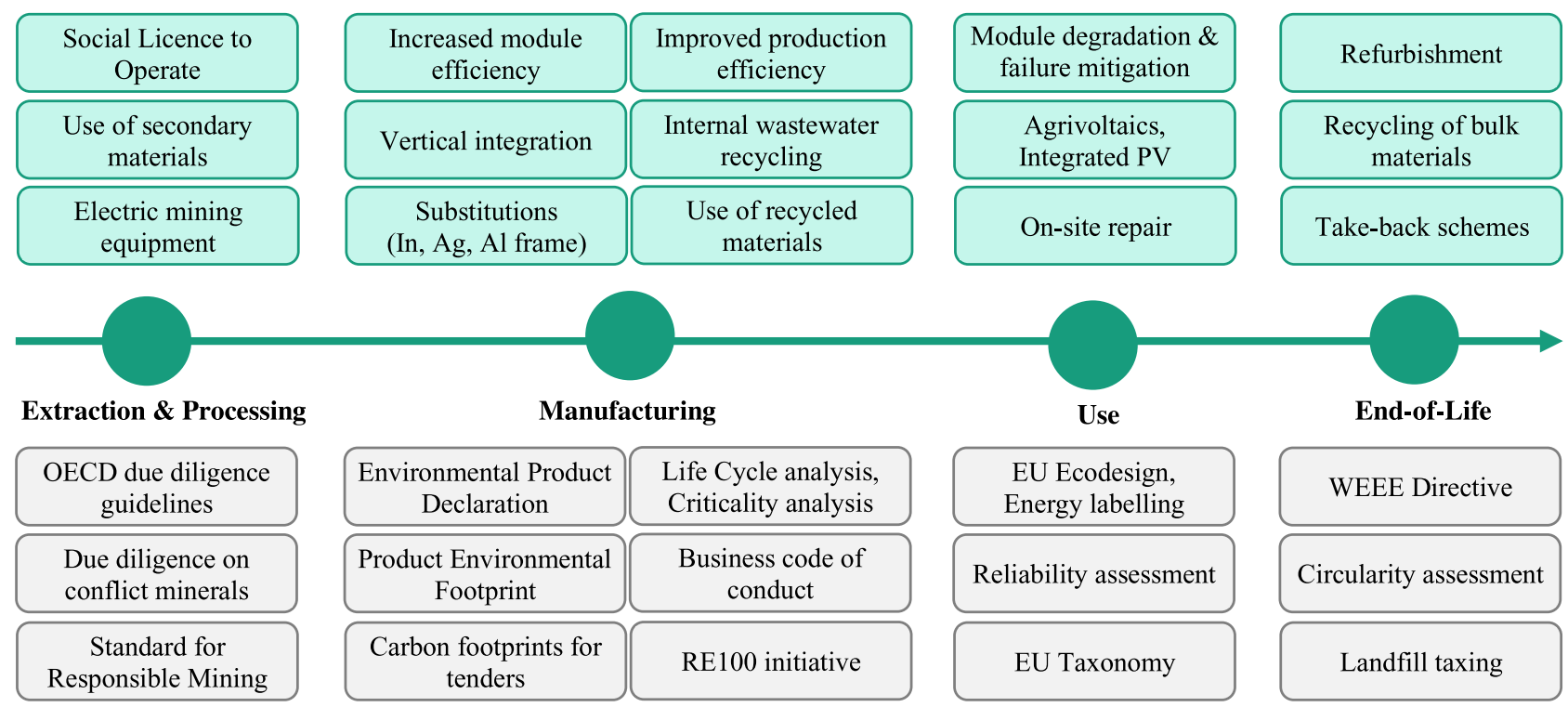

Fig. 1. Excerpt of the sustainability landscape over the PV value chain. Practices implemented or in development for industrial applications are in green; policies, research instruments and standards are in grey.

there is no consensus on how to measure circularity [10] and criticality [11] and integrate them into product development. Social LCAs (s-LCA) show low maturity. Performances as reported by PV manufacturers can be characterized by limited data transparency and lack of common assessment frameworks [12].

In this paper, we review the sustainability challenges that lie ahead of the PV sector and provide insights on how to improve existing shortcomings. The scope of analysis complements in 2 ways the very few recent studies benchmarking best practices for environmental, social and governance (ESG) factors in PV $[13,14]$. First, the concept of sustainability as proposed by the United Nations Sustainable Development Goal 12 (SDG 12) "responsible consumption and production" is hereby used. Its framework covers a broad range of sustainability topics including material supply risks, wastewater treatment and public reporting, commonly excluded from the ESG factors as the latter remain to date uncoordinated. Second, methodological needs to improve sustainability assessment and accounting in PV are systematically discussed. Implementing the right instruments and indicators to evaluate progress towards sustainability is a crucial and ongoing task. This paper aims therefore at providing fuel to the complex sustainability discussion and paving the way for a structured course of action in the PV sector.

\section{Mapping the PV sector to SDG 12}

SDG 12 calls for the implementation of sustainable consumption and production patterns. According to the $\mathrm{UN}$, it is about "doing more and better with less. It is also about decoupling economic growth from environmental degradation, increasing resource efficiency and promoting sustainable lifestyles" [15]. Although the Goals are originally formulated for nations, SDG 12 is particularly adapted for translating the global needs into business practices. It is a holistic approach broken down into 8 topics. Sustainability targets in accordance with SDG 12 were defined by Gervais et al. for the PV sector [12]. A gap analysis highlighted a need for progress in 16 areas or "sustainability strategies" displayed in Table 1.

The framework brings together different sustainability topics, from environmental aspects to social responsibility. Not unifying the current specialized approaches poses otherwise the risk of an inefficient sustainable development for PV: some initiatives might not be further pursued if it is not clear how they are supposed to fit in the "big picture". Some aspects of sustainability such as social ones might be overlooked while cost-driven practices might not be sufficiently ambitious if they are not recognized as sustainability targets. PV modules, their related production processes and end-of-life are hereby focused on. BOS elements are excluded. Sustainability strategies associated with the installation and operation of PV plants are not listed but could a priori also be integrated in the SDG 12 framework (e.g., land as a natural resource).

This paper builds upon the previously developed SDG 12 framework and specifies what can be done to address each sustainability gap.

\section{Addressing the sustainability gaps}

Each gap can potentially be the focus of extended investigation and dedicated research projects. For the sake of conciseness, this paper discusses 3 topics in more details. "Improve the supply security of products", "optimize the treatment of production line outputs" and "extend the use phase of products" are the subject of this 
Table 1. Sustainability targets and strategies for the PV sector under the lens of SDG 12 [12].

\begin{tabular}{|c|c|c|c|}
\hline \# SDG & Topic & Target for the PV sector & Sustainability strategy for the PV sector \\
\hline 12.1 & Instruments & $\begin{array}{l}\text { Collectively support coherent } \\
\text { sustainable practices in the PV } \\
\text { sector }\end{array}$ & $\begin{array}{l}\text { Define common sustainability goals with all } \\
\text { stakeholders } \\
\text { Implement methodology to assess progress } \\
\text { towards sustainability }\end{array}$ \\
\hline 12.2 & Natural resources & $\begin{array}{l}\text { Achieve the sustainable } \\
\text { management of natural } \\
\text { resources }\end{array}$ & $\begin{array}{l}\text { Reduce material intensity } \\
\text { Reduce water use } \\
\text { Reduce (fossil-fuel based) energy consumption }\end{array}$ \\
\hline 12.4 & $\begin{array}{l}\text { Hazardous waste } \\
\& \text { Chemicals }\end{array}$ & $\begin{array}{l}\text { Achieve the environmentally } \\
\text { sound management of chemicals } \\
\text { and wastes }\end{array}$ & $\begin{array}{l}\text { Optimize the treatment of production line } \\
\text { outputs } \\
\text { Avoid the release of harmful substances } \\
\text { during extraction, use and EoL }\end{array}$ \\
\hline 12.5 & Waste generation & $\begin{array}{l}\text { Substantially reduce PV } \\
\text { material waste generation }\end{array}$ & $\begin{array}{l}\text { Increase the collection rate of EoL modules } \\
\text { Extend the use phase of products } \\
\text { Increase the efficiency of EoL recycling } \\
\text { Increase the use of recycled materials in } \\
\text { production }\end{array}$ \\
\hline 12.6 & CSR \& reporting & $\begin{array}{l}\text { Ensure stakeholder well-being } \\
\text { and demonstrate sustainability } \\
\text { commitment }\end{array}$ & $\begin{array}{l}\text { Standardize sustainability reporting } \\
\text { Standardize corporate social responsibility } \\
\text { (CSR) practices }\end{array}$ \\
\hline 12.7 & $\begin{array}{l}\text { Sustainable } \\
\text { procurement }\end{array}$ & $\begin{array}{l}\text { Adopt sustainable procurement } \\
\text { practices }\end{array}$ & $\begin{array}{l}\text { Improve the supply security of products } \\
\text { Ensure the social and environmental } \\
\text { performances of suppliers }\end{array}$ \\
\hline 12.8 & Public awareness & $\begin{array}{l}\text { Inform consumers on the } \\
\text { sustainability of product/ } \\
\text { company }\end{array}$ & $\begin{array}{l}\text { Democratize sustainability labelling for PV } \\
\text { modules }\end{array}$ \\
\hline
\end{tabular}

focus. Approaches to address the remaining gaps are nonetheless discussed and insights on how to improve sustainability assessment and accounting given.

\subsection{Improve the supply security of products}

The need for critical raw materials in energy technologies is a known issue [16]. Regulation bodies have also taken up on this concern. For example, in Germany, the raw materials strategy of the federal government aims at supporting industries with a secure, responsible and sustainable material supply [17]. It entails 17 measures such as promoting raw material extraction in Europe, supporting sustainable raw materials management in developing countries and enabling R\&D projects for circular economy.

As for PV, bottleneck risks concern both thin films and silicon-based modules: $11 \%$ of polysilicon, $1 \%$ of ingots and wafers, $0.4 \%$ of cells and $4 \%$ of solar modules were produced in Europe in 2019 [18]. The PV glass production is also dominated by the Chinese industry. To mitigate the supply dependency of the EU, the European Raw Material Alliance (ERMA) and the European Solar Manufacturing Council (ESMC) advocate for strengthening local PV manufacturing and recycling capacities. Despite ongoing projects to re-build EU production from ingot to module [19], the demand for specific metals remains worrisome.
Even more so as the increasing market capacity for heterojunction (HJT) solar cells as well as upcoming cell technologies like silicon-perovskite-tandem cells require critical materials such as indium in their transparent conductive oxide (TCO) [20].

To exemplify the demand-to-supply constraints existing for certain resources, the yearly indium requirements to deploy an increasing market capacity of HJT solar cells are herein assessed. The share of indium demand covered by closed-loop recycling is calculated based on the methodology proposed in [21]. Different scenarios are defined:

- The scenario "Baseline" represents the indium requirements for state-of-the-art HJT cells: $70 \mathrm{~nm}$ thick indiumtin-oxide (ITO) layers per side with $90 \% \mathrm{In}_{2} \mathrm{O}_{3}$ weight content hold $3.77 \mathrm{mg}$ indium per $\mathrm{Wp}$ for a $21 \%$ module efficiency. Considering a deposition success rate for sputtering of $50 \%$ and a production scrap recycling efficiency of $65 \%$ per recycling cycle, $5.09 \mathrm{mg}$ primary indium are required per $\mathrm{Wp}$.

- The scenario "Thin" assumes a reduction of the total ITO layer thickness down to $90 \mathrm{~nm}$, resulting in a primary indium demand of $3.27 \mathrm{mg} / \mathrm{Wp}$.

- The scenario "Progress" combines a reduction of the ITO layer thickness with a module efficiency increase up to $25 \%$ and a sputtering efficiency of $80 \%$ [20]. It results in a primary indium demand of $2.76 \mathrm{mg} / \mathrm{Wp}$. 

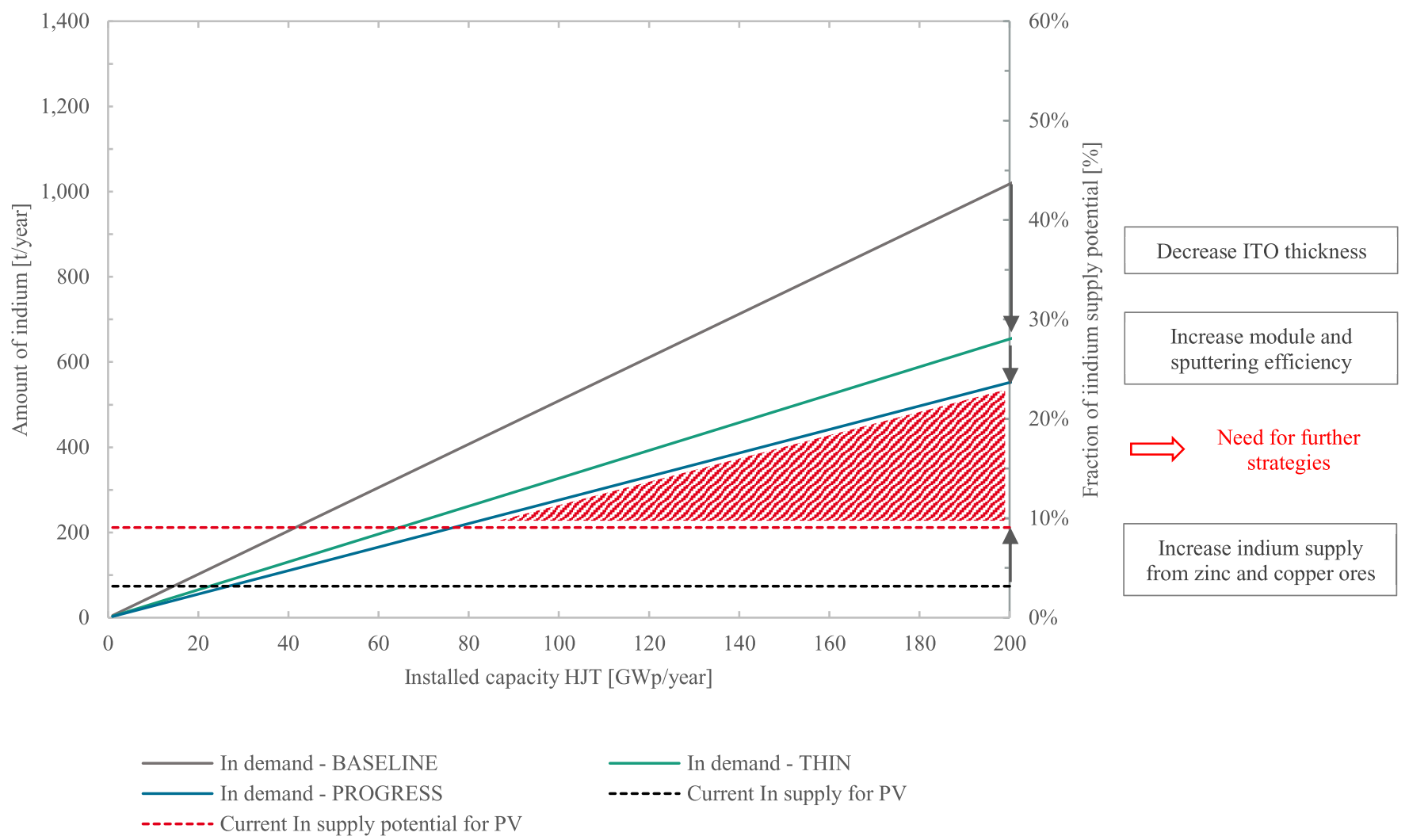

Fig. 2. Comparison of the indium demand for HJT deployment with the current annual indium supply and indium supply potential for PV.

Figure 2 shows the indium requirements to deploy HJT for the different scenarios. The material demands are compared to threshold values set by the indium supply. Around $9 \%$ of the global indium production is currently allocated to the PV sector [22], the rest is mainly used in flat panel displays and solders. On average, 74 tons of indium are therefore available annually for the PV sector [23]. Assuming that indium would not be additionally required for CIGS or tandem $\mathrm{PV}$ technologies, this would allow the installation of around 15-30 GWp/year of HJT depending on the scenario.

The current production cannot however solely account for the indium availability. As identified by Frenzel et al. [24], there is a discrepancy between the present primary production of indium and its current supply potential, which is around 3 times higher. Overlooking this differentiation inevitably leads to pessimistic results. The current supply potential is defined as "the amount of by-product extractable per year from the ongoing primary production [...] given current price-levels and extraction technologies" [24]. Based on this parameter reflecting more realistically the indium supply situation, a minimum of 40-80 GWp HJT could be installed annually depending on the scenario. Targeting significantly higher installed capacities, i.e., on a terawatt-scale, would require drastic strategies to match demand and supply.

This result needs to be interpretated with caution. It is more a warning on the order of magnitude of solar deployment than a hard limitation on raw material supply, which is depicted in a simplified manner. Concurrent indium demand for other solar cell concepts, future share of the indium supply allocated to PV, efficiency measures on the demand and supply sides as well as expansion of supply capacities will undoubtedly change the material accessibility.

Geopolitical, resource nationalism and logistic-related constraints are also crucial to monitor as part of an extended risk or criticality assessment, as they are most likely to cause short-term unavailability. Overall, such distance-to-target approaches are helpful to guide technology development for next-generation cell concepts and prepare criticality mitigation strategies such as favorable supply trades. They need to be regularly updated to account for the dynamics of supply risks. Finally, the systemic impacts of criticality mitigation strategies are to be assessed to avoid negative rebound effects: As an example, substituting lead with bismuth in soldering to avoid dealing with the lead toxicity might have counter effects as bismuth is a by-product of lead and has as such a relatively constrained supply [20].

\subsection{Optimize the treatment of production line outputs}

The main chemical hazards related to the crystalline silicon industry are silicon tetrachloride waste, lead, acid and caustic wastewaters, solvents, dopants, silane and overall waste gases with high global warming potential [25]. A focus on wastewaters and waste gases occurring in the cell fab is herein provided. 
Table 2. Overview of standards regulating effluent discharges.

\begin{tabular}{|c|c|c|c|}
\hline Standard & Discharge type & Nitrogen $(\mathrm{mg} / \mathrm{l})$ & Fluoride $(\mathrm{mg} / \mathrm{l})$ \\
\hline $\begin{array}{l}\text { EU Best Available Techniques for waste } \\
\text { treatment }\end{array}$ & Direct & $10-60$ & $0.2-1$ \\
\hline German Drinking Water Directive & Direct & 11 & 1.5 \\
\hline $\begin{array}{l}\text { EHS Guidelines for Semiconductors \& } \\
\text { Other Electronics Manufacturing }\end{array}$ & Direct & $\mathrm{n} / \mathrm{a}$ & 5 \\
\hline Chinese National Standards & Indirect & 45 & 20 \\
\hline $\begin{array}{l}\text { Chinese standard for PV } \\
\text { (GB 30484-2013) }\end{array}$ & Indirect & 40 & 8 \\
\hline $\begin{array}{l}\text { Jiangsu Prov. Ordinance of Tai Lake } \\
\text { Water Pollution Prevention \& Treatment }\end{array}$ & Indirect & $<15$ & $<5$ \\
\hline EPEAT Ecolabel for PV (NSF/ANSI 457) & \multirow{2}{*}{\multicolumn{3}{|c|}{$\begin{array}{l}\text { - Inventory of water use and wastewater effluent* } \\
\text { - Documentation of wastewater quality (min. COD, BOD, TSS, } \\
\text { heavy metals, pH) } \\
\text { - No violation of discharge permits* } \\
\text { - Optimization of process chemicals in effluent } \\
\text { - Drinking water quality standards for all water leaving the } \\
\text { facility }\end{array}$}} \\
\hline Cradle-to-Cradle & & & \\
\hline
\end{tabular}

* Minimal requirement.

For wastewater, the concentrations of fluoride and nitrogen resulting from the use of hydrogen fluoride and nitric acid are of particular importance from an environmental perspective. The discharge limits applying to the PV industry are however highly dependent on the plant location. Table 2 shows some of the main standards regulating effluent discharge as well as the requirements regarding wastewater as formulated by the Cradle-toCradle [26] and EPEAT [27] sustainability labels. For comparison, the effluent quality for drinking water in Germany [28] and according to the EU Best Available Techniques for waste treatment [29] is also displayed. Direct discharge means that the wastewater is discharged into a receiving water body without prior treatment. Indirect discharge refers to wastewater sent to a wastewater treatment plant.

The Chinese PV industry must comply with the GB 30484 standard and the Environmental Protection Bureau can enforce stricter requirements locally. For example, this is the case for the Tai Lake Basin where major PV manufacturing plants are located. The area has experienced dramatic pollution endangering drinking water supply. As a result, the Jiangsu Province applies specific discharge limits. The sequence of processes fluoride precipitation, neutralization and nitrification/de-nitrification enables PV manufacturers to comply with these limits. Due to the heterogeneity of the standards at local, regional, and national levels, striving for low targets for nitrogen and fluoride is however left to the decision of manufacturers. An optimization of process chemicals in effluent is also not a minimal requirement to qualify for sustainability labels.

As for waste gases, the emission of nitrogen oxides (NOx) and volatile organic compounds (VOCs) in the cell fab is linked to high global warming potentials. Thermal oxidation largely eliminates the VOCs but is not systemically implemented by manufacturers in the absence of regulation. Thus, the concentration of VOCs, if at all reported by top tier manufacturers, can range from $2 \mathrm{mg} / \mathrm{m}^{3}$ to $20 \mathrm{mg} / \mathrm{m}^{3}$.

Only little data on the emissions of hazardous substances are made publicly available by manufacturers. A systematic minimal reporting on the concentrations of nitrogen, fluoride, NOx and VOCs might foster progress on their handling. A harmonization of regulations could also accelerate the cost-internalization for more performant treatment processes. Effluents are currently mixed before leaving the plant. Another approach to reduce chemical use and freshwater degradation per MW produced would be the separation and re-circulation of chemical flows for specific chemical process baths. The techno-economic feasibility of adapting manufacturing plants for point-ofuse recycling requires further research.

\subsection{Extend the use phase of products}

The extension of a product useful life is critical to keep materials in the market for a longer time frame, minimize resource extraction and waste. Especially for PV as energy producing technology, lifetime energy output is significant for the overall resource efficiency, which is the ratio of a given benefit to the input of natural resources required to achieve it. Thus, resource efficiency cannot only be increased by higher cell and module efficiencies, but even more effectively by extending the systems lifetime through measures like repair and reuse or degradation prevention.

Defects or failures often occur in only one component while the rest of the module remains intact. Repair of modules in the field would be desirable to keep costs low, 
but also the refurbishment and resale of modules is relevant to prolong the modules useful lifetime. A growing number of second-life modules is being sold on the market, but standards to prove quality or certificates to verify stability are yet missing, which makes it hard for providers to compete [30]. Few practicable approaches are currently available, although the topic of lifetime extension is beginning to gain relevance in research, industry, and policy. Repairability is explicitly addressed in the Ecodesign/Energy Labelling draft legal proposal of the EU Commission [31] for failure-prone and easy to access module parts like junction box and bypass diodes. Options for the repair of cracked backsheets in the field are successfully being tested [32].

To promote those measures, action is needed from different kinds of stakeholders. Standardization on quality and safety for second-life modules must be implemented as well as legal requirements on repairability and design-forrepair. Also, research on degradation prevention and performance loss rate determination is in demand to provide guidance for structural health monitoring to system operators.

Although efforts in this area of action are evident, this gap is especially hard to address by research and policy because it involves not only manufacturers, but also requires strong engagement from system operators. Currently, the replacement of damaged PV modules with new modules is usually cheaper than its repair, although repair would be possible in many cases. Incentives for repair and refurbishment in the form of sustainable finance criteria that reward the sustainable management of $\mathrm{PV}$ installations could be a lever to stimulate PV plant operators. Realistically, refurbishment can be difficult for long-life products such as solar panels, as parts for older systems might become hard to find. Tailored assessments are required to weigh the environmental pros of repaired products against potential cons, for instance related to shipment and repowering in other countries or regarding innovation advancements in PV. Degradation rates and lifetimes are further parameters to consider in the prioritization of novel module designs.

The following sustainability gaps are not analyzed in detail.

\subsection{Reduce material intensity}

A lifecycle inventory is necessary to determine the total raw material demand from raw material extraction to module recovery and must include components of the PV system, as well as production losses, auxiliary materials, and utilities. The unused extraction, i.e., the materials that have to be moved to gain access to the coveted materials and particularly mining waste (e.g., tailings) should further be taken into account [33].

Instead of targeting overall resource efficiency through increased module performance, individual raw materials should be prioritized for the development of reduction measures. This selection needs to be based on environmental, social, and economic considerations combined. For instance, around $10 \%$ of primary silver production is estimated to be linked to artisanal and small-scale mining which relies on a mostly unskilled workforce and is associated to poor health and safety practices. Silver mining shows further high environmental hazard potential as it might be linked to acid mine drainage, heavy metal concentrations in deposits and toxic chemicals use for extraction and processing [34]. Silver also accounts for $10 \%$ of PV module costs [35] while having volatile prices.

Cell design adaptations such as increasing number of busbars, thinner wafers are already paving the way towards a reduced use of selected materials. More ambitious approaches such as kerfless wafering or frameless modules promise further reductions. Short-term targets for material intensity reduction beyond considerations on material cost savings need to be defined, publicly reported by corporates and their environmental and social impacts assessed.

\subsection{Reduce water use}

A report from the IEA-PVPS Task 12 estimated the life cycle water consumption of electricity generated in Europe by mono-Si PV systems at $1.5 \mathrm{l} / \mathrm{kWh}[36]$. The related water stress impact was found to be driven by the electricity supply, mainly conventional, for manufacturing. Energy efficiency measures and greener electricity mix for polysilicon and ingot production would reduce the PV related water scarcity. Wastewater recycling to reduce freshwater use is further commonly implemented by top tier PV manufacturers: e.g., reuse water from post-cleaning baths in pre-cleaning baths in wafer fab, reuse reverse osmosis rejected water, reuse water from air conditioning for cooling tower. Enhancing wastewater recycling would imply changing the way manufacturing plants are conceived. This requires cost-effective, turnkey design solutions for plants.

The research community on water footprints suggests that implementing water efficiency measures at suppliers with water hotspots might be environmentally more beneficial than acting on domestic production-sites [37]. This means that manufacturers need to go beyond the typically measured water use volume by assessing indirect water use along supply chains and associated local impacts, e.g., on freshwater scarcity as recommended by the PEFCR for PV modules [38], human health and biodiversity.

\subsection{Reduce (fossil-fuel) based energy consumption}

Electricity to produce PV components plays a major role in their environmental impacts. Several PV manufacturers are already committing to sourcing $100 \%$ of their electricity from renewable sources via the RE100 initiative [39]. Practically, corporates can purchase renewable energy certificates, preferably with an additionality term, thus ensuring that the company's investment directly contributed to new renewable energy capacities. Establishing production activities in regions with low-carbon electricity mixes has further shown great improvements on carbon 
emissions [7]. Overall, the growth of energy demand for expanding PV production is expected to represent a substantial part of the $1.5^{\circ} \mathrm{C}$ greenhouse gas emission budget, therefore calling for further improvements in energy efficiency [40]. Polysilicon and Cz-crystal production being the most energy and emission-intensive steps, they are to be prioritized for such measures. Low-cost polysilicon as produced in China is still dominantly supported by coal-fired power stations. Using upgraded metallurgical grade silicon instead of polysilicon from the conventional Siemens process has the potential to reduce the energy payback time of the solar electricity generated by $25 \%$ [41]. The trade-off between limited module performances resulting from lower purity grade and the lower energy consumption and associated climate impacts needs to be taken into consideration.

On a methodological note, it is controversial if supplier specific electricity mixes or country specific electricity mixes should be used to avoid potential double counting of renewable energy resources. The need for updated data on electricity mixes has further been identified as a barrier in LCA to account for climate change impacts.

\subsection{Avoid the release of harmful substances during extraction, use and end-of-life phases}

As prescribed by the EPEAT ecolabel for PV modules [27], IEC 62474 declarable substances and Substances of Very High Concern (SVHC) on the EU REACH Regulation List and Candidate List present in PV systems are to be disclosed or avoided altogether. Substances of concern in packaging should also be eliminated. As for decommissioning, the cost of recycling is higher than landfill [3]. Policies have a role to play to improve waste management for instance in the form of extended producer responsibility as applied in the EU, landfill banning or subsidies to encourage PV owners to recycle [42].

Some of the restricted substances play an undeniable role in $\mathrm{PV}$ modules, and while some can be reduced or replaced (e.g., lead in cell interconnections), others are viable for the modules functionality (e.g., Cadmium in CdTe modules or lead in Perovskite modules). Since strategies of reliable containment have yet to prove applicability in a range of medium to worst case scenarios, progress on the use of alternative materials should further be made.

LCA evaluate environmental impacts from cradle to grave. Most assessments for PV have however a focus on production and use, with fewer data on the end-of-life phase [10]. While raw material extraction is typically included, a realistic modelling of mine tailings management and disposal is still a work in progress [43]. Improving the available data sets for extraction and end-of-life would contribute to a better assessment of environmental impacts. Optimally, detailed data on the material composition of a module should further accompany its entire life and be made available to recyclers. Knowing if fluoride-based backsheet, flame retardants or heavy metals are present in the product, recyclers could identify and implement safe, efficient recovery strategies and avoid health or environmental hazards.

\subsection{Increase the collection rate of modules}

Improving the current collection of used panels requires standardized take-back schemes, infrastructure and trained workforce to properly handle the modules [44]. Module traceability is also a necessary tool for regulators to ensure the compliance of producers and owners with disposal regulations and for the research community to better understand global waste flows. The sorting of used modules, coupled to the collection phase, is further of prime importance. An end-of-life decision tool could support the selection of an adequate route for the module between reuse, repair, and recycling. Besides technical characterization of the module, it should entail a sustainability assessment for each route to make an informed, fact-based decision over all dimensions of sustainability.

\subsection{Increase the efficiency of EoL recycling}

The WEEE Directive specifies minimum targets for PV of $85 \%$ recovery and $80 \%$ preparation for reuse and recycling. These targets are presently achieved by recycling aluminum, glass, and copper. The laminate residues are landfilled after shredding and incineration. Solar glass is downcycled to flat glass [10]. High-value recycling for silicon-based modules is still experimental but already shows positive results with the recovery of silver and silicon [3]. Due to current low and irregular waste flows, a trade-off between the purity grade of secondary materials and the processing costs needs to be found. Material-specific recycling targets and collaborative recycling schemes across countries to treat larger quantities might change the situation. Design for dismantling, including reducing the complexity of alloys and materials portfolio, could also enhance the circularity of PV modules.

Circularity assessments are further linked to substantial methodological and data-related challenges [10]. Modelling closed loops and assessing their sustainability is still a work in progress. The lack of data on material quality losses during recycling processes and accumulation of contaminations through product re-circulation needs to be addressed.

\subsection{Increase the use of recycled materials in production}

While some requirements are already covered by secondary sources (e.g., new scrap closed-loop recycling for the ITO), this is not systematically the case for most materials, such as silicon. The unknown or low-quality of secondary materials often hinders their large-scale use in PV production. The Siemens process being highly energyintensive, recovering silicon at solar grade instead of metallurgical grade from kerf and end-of-life recycling would for instance considerably drive down the power consumption and $\mathrm{CO}_{2}$ emission per module [45]. Overall, 
the qualitative and quantitative requirements for secondary materials to have sustainability impacts upon use in PV need to be standardized and their effects on module efficiency identified.

The acceptance of PV manufacturers to use secondary materials will further depend on the cost of primary raw materials. Instruments such as virgin material taxes, environmental taxes and subsidies to the recycling sector might individually have limited impact on developing a circular economy: an economic comprehensive framework to enhance secondary material use is still under research [46].

\subsection{Standardize sustainability reporting}

Most top tier PV module manufacturers already publish sustainability or corporate social responsibility reports in a regular way and use the Global Reporting Initiative (GRI) standards on a voluntary basis. The parameters typically disclosed include [12]: water use, wastewater generation, energy consumption, scope 1 and scope 2 emissions, commitment to environmental standards (e.g., RE100), hazardous waste generation, number of accidents, characterization of the workforce (e.g., number of employee, share of female employees), anti-corruption policy, training hours, philanthropic activities, supplier assessment framework, environmental certifications (e.g., ISO 9001, ISO 14001, OHSAS 18001).

This paper invites manufacturers to broaden the scope of their reporting to the sustainability gaps commonly overlooked, e.g., reduction of material intensity, use of recycled content, and treatment of production line outputs. Key Performance Indicators (KPIs) should be standardized and complemented by context-based or science-based sustainability approaches where relevant. Setting internal, ambitious, and preferably measurable goals and timeframes is key to a high-quality reporting.

\subsection{Standardize corporate social responsibility (CSR) practices}

CSR frameworks such as the handbook "Solar Industry Commitment to Environmental \& Social Responsibility" [47] or the "Diversity Best Practices Guide for the Solar Industry" [48] are already available to the PV industry. Complementary to international human and labor rights, they provide guidelines for corporates to define their internal business code of conduct. Photovoltaic manufacturing being related to chemical hazards, a strict environmental, health and safety management is of prime importance to reduce the exposure of employees and local communities.

As for many industries, enhancing labor rights, diversity and inclusion will require active commitment and adequate methods to measure progress. Quantitative KPIs are deemed more efficient to address social issues than qualitative codes of conduct. The indicators are to be carefully chosen to avoid blind spots [49]. For instance, monitoring the share of female employees reflect only partially a corporate culture for gender equality. Further
KPIs such as \% female in managerial position, \% genderbased violence or health related incidents or $\%$ gender pay gap by occupational category are only a few examples providing a more granular vision.

\subsection{Ensure the social and environmental performances of suppliers}

Corporates are expected to take full responsibility for the supply chains associated with their goods and services. This is however mostly done on a voluntary basis in the PV sector, as regulations only concern a few countries (e.g., newly adopted Germany's Due Diligence Act) or specific raw materials (e.g., tin as a conflict mineral). The adoption of mandatory due diligence legislation for instance at EU scale could foster progress in human rights and environmental standards and create a level playing field. As already done by some top tier manufacturers, suppliers and their environmental and social performances can be fully disclosed in sustainability reports.

In particular, raw material procurement for the $\mathrm{PV}$ industry needs to gain in transparency and traceability via third-party verification. The Certification of Raw Materials (CERA) [50] is for instance a standardized certification scheme ensuring environmental, social and economic sustainability in extraction, processing and trading. Such schemes could be used in PV supply chains. Distributed ledgers such as blockchain are a promising tool to support supply chain due diligence and should be tested for PV. Challenges regarding data-quality and implementation costs need to be addressed in the process.

\subsection{Democratize sustainability labelling for PV modules}

Sustainability labels are a tool to inform consumers that not all PV modules are equal and empower them to actively support better alternatives. The Cradle-toCradle and the EPEAT ecolabels have been awarded to only a few PV products up to now. They provide a comprehensive assessment framework which can support overall sustainability progress. Their impact will however depend on whether consumers are aware of the existence of such labels and understand what they entail. Overall, communicating progress from the PV sector in terms of sustainability might increase the social acceptance of solar energy.

\subsection{Implement methodology to assess progress towards sustainability}

Although sustainability is complex to define and practically grasp, there is a wide consensus on the need to interpret sustainability over three impact dimensions: environmental, social and economic ones. Accordingly, the Life Cycle Initiative promotes a Life Cycle Sustainability Assessment framework (LCSA), in which LCA, s-LCA and Life Cycle Costing (LCC) are performed separately to the same case study [51]. This enables the identification of trade-offs between the three pillars, informing decision- 
making. LCSA is still at an early stage of consolidation, applications to PV could fuel the discussion to identify sectoral specific methodological recommendations. Since benchmarks for standards and regulations are often based on life cycle calculations, not only a harmonized methodological approach is necessary, but also the harmonization and the timeliness of underlying data and databases are required to ensure a fair competition between stakeholders.

Overall, tools are needed to go from carbon-centric approaches to multidimensional assessments. This implies also accounting for the interlinkages between sustainability strategies. Reduce material intensity, increase energy efficiency, and implement circularity strategies are often cited as main levers to act on climate change. These strategies are further intrinsically related to water footprint, sovereignty and social impacts which can in turn be quantified as well.

\subsection{Define common sustainability goals with all stakeholders}

As shown by best-practice examples in the PV sector, sustainability goals are prioritized at corporate level by materiality analysis: in collaboration with the stakeholders (e.g., investors, customers, employees), issues are ranked by priority, thus steering the sustainability strategy of the company.

Recognizing that each company has its own specificities and goals, a sustainability roadmap at sectoral scale can be a complementary tool to define overarching courses of action towards more sustainability. It could demonstrate a united front from the PV sector in addressing the global needs defined by the SDGs and contribute to the green reputation of PV by being fully transparent on its strengths and areas of improvement.

In that sense, the main practical approaches developed under Section 3 to address each of the sustainability gaps are compiled in Table 3 . The resulting list of actions is by no means intended to be exhaustive but rather provides a starting point for stakeholders to conform with SDG 12 .

\section{Conclusion}

$\mathrm{PV}$ is globally recognized as a viable energy option to decarbonize power systems. It will play a central role to achieve climate targets while contributing to increased energy access to marginalized populations and economic development via job creation. Given the projected terawatt-scale PV deployment, it is critical for the sector to acknowledge its areas of improvement from a sustainability perspective and address these.

In this paper, practical approaches for the PV sector to address its sustainability gaps in the context of SDG 12 have therefore been proposed. Multiple policy instruments, industrial best-practices and research trends already pave the way towards more sustainability overall and in PV. Environmental Product Declaration, Ecodesign, ISO norms, OECD Due Diligence Guidelines, EU guidelines on non-financial reporting are only a few examples of this sustainability landscape. This work provides a complementary take on PV sustainability by compiling practical considerations for all dimensions of sustainability, from resource use and environmental impacts to corporate social responsibility, supply risk management and reporting. It also provides insights on methodological needs to improve sustainability assessment and accounting for PV, as these are still a work in progress.

Of all the approaches proposed to address the sustainability gaps, enhancing data collection along the entire PV value chain is a cross-cutting topic. Tracking material flows and products with an accompanying sustainability assessment at each life-cycle phase would be a way to identify real-life social, economic, logistical, and environmental hotspots. This is linked to substantial challenges regarding the development of adequate life-cycle sustainability assessments including circularity analysis, data quality, closing data gaps and safe yet auditable data exchange processes. The PV sector can learn from the ongoing experiences in this area such as the Battery Passport introduced by the EU.

Finally, this paper raises the question of when sustainability is truly achieved and how to assess it. The Key Performance Indicators in use commonly measure incremental progress: e.g., a module manufacturer reduced its water intensity by $5 \%$ compared to the year before. At most, performances are compared to an industry average or best-practice value: e.g., the environmental impacts of a company are $10 \%$ lower than the EU average. These indicators say little about how performant the PV sector is in respecting the planetary boundaries. Context-Based Sustainability might be a method to measure corporate impacts against thresholds for what the impacts would have to be to ensure human well-being and maintain world resources [52]. It is to date not standardized. Overall, adequate assessment and accounting to measure progress towards the SDGs will support more sustainability in PV value-chains.

\section{Author contribution statement}

E. Gervais: Conceptualization, Investigation, Methodology, Writing - Original Draft, Review \& Editing; S. Herceg: Writing - Original Draft, Review \& Editing; S. Nold: Review \& Editing; K.-A. Weiß: Supervision \& Funding acquisition.

This work was supported by the Fraunhofer Innovation Program within the research project "Souveräne Wertschöpfungszyklen SVC". The authors would like to thank the project partners for the constructive collaboration and two anonymous reviewers for their comments. The authors also thank Lorenz Friedrich and Martin Bivour for the discussions on indium demand. 
Table 3. List of actions for the PV sector to address SDG 12. It is by no means exhaustive but provides a starting point for all stakeholders to improve the sustainability in PV value chains.

Sustainability strategies for the PV sector
Define common sustainability goals with all
stakeholders
Implement methodology to assess progress
towards sustainability

Reduce primary material intensity

Reduce water use

Reduce (fossil-fuel based) energy consumption

Optimize the treatment of production line outputs

Avoid the release of harmful substances during extraction, use and EoL phases

Increase the collection rate of EoL modules

Extend the use phase of products

Increase the efficiency of EoL recycling

Increase the use of recycled materials in production
What work remains to be done

- Prioritize sustainability issues at corporate level by materiality analysis

- Define and commit to a common PV sustainability roadmap at sectoral level to address the SDGs

- Set quantitative sustainability targets for the PV sector

- Advance applicability of LCSA to PV

- Integrate multidimensional considerations (e.g., impact on SDGs) in the conception of sustainability strategies

- Expand and harmonize datasets for LCAs, criticality, and circularity analyses

- Prioritize raw materials for efficiency measures based on sustainability assessment

- Accelerate the switch to far-less material intensive production techniques

- Integrate considerations on material waste in upstream supply chain in supplier selection

- Standardize wastewater recycling measures

- Analyze the techno-economic feasibility of alternative plant conceptions to enhance water recycling

- Identify hotspots related to water footprint in the supply chain

- Source electricity from renewable energies

- Strive towards energy-efficient production buildings

- Advance technologies with low energy consumption for polysilicon production

- Disclose treatment of silicon tetrachloride waste, acid and caustic wastewaters, solvents, dopants, and silane

- Standardize lower discharge limits

- Analyze the techno-economic feasibility of alternative plant conceptions for re-circulation of chemical flows

- Improve data availability for impacts occurring during extraction and end-of-life

- Reduce/replace restricted substances in PV products or implement robust containment strategies

- Inform recyclers on material composition of used panels

- Standardize take-back regulatory schemes and develop collection infrastructure

- Develop end-of-life decision tool (reuse, repair, recycle) for PV modules including a sustainability assessment

- Enable module traceability during use and end-of-life

- Standardize quality and safety warranties for second-life modules

- Implement legal requirements on repairability and design-for-repair

- Support repair via dedicated research on degradation prevention and financial instruments

- Improve data availability on material quality losses during recycling

- Standardize circularity assessments and modelling of closed loops in LCA

- Advance research on cost-efficient high-value recycling for siliconbased modules and design-for-dismantling

- Standardize quality requirements for secondary materials for use in $\mathrm{PV}$ and minimum recycled content

- Prioritize secondary materials to be used based on sustainability assessment

- Advance research on financial instruments to support circularity 
Table 3. (continued).

\begin{tabular}{ll}
\hline Sustainability strategies for the PV sector & What work remains to be done \\
\hline Standardize sustainability reporting & - Include reporting on total primary material intensity, production \\
& line outputs and use of recycled content \\
& - Standardize quantitative Key Performance Indicators (KPIs) \\
& - Set internal goals for the KPIs and display progression over the \\
& years \\
& - Prefer quantitative KPI to describe social issues rather than \\
& qualitative codes of conduct, where possible \\
Standardize Corporate Social & - Adopt meaningful indicators to avoid blind spots in social issues \\
Responsibility (CSR) practices & - Assess progress in CSR practices \\
& - Analyze the risks related to raw material use via criticality \\
& assessments \\
Improve the supply security of materials & - Integrate risk assessment already at product development stage \\
and products & Analyze the systemic impacts of criticality mitigation strategies over \\
& all dimensions of sustainability \\
& - Adopt sustainability certification schemes for mineral value chains \\
& - Disclose suppliers and their sustainability performances in regular \\
Ensure the social and environmental & reporting \\
performances of suppliers & - Advance research on product tracking related challenges as data \\
& gaps, data quality and data exchange processes \\
& - Increase number of PV products with sustainability label \\
& - Inform consumers on sustainability labels for PV \\
& - Communicate sustainability performances of the PV sector \\
\hline
\end{tabular}

\section{References}

1. P. Viebahn, O. Soukup, S. Samadi, J. Teubler, K. Wiesen, M. Ritthoff, Renew. Sustain. Energy Rev. 49, 655 (2015)

2. D. Mulvaney, IEEE Spectr. 51, 30 (2014)

3. R. Deng, N.L. Chang, Z. Ouyang, C.M. Chong, Renew. Sustain. Energy Rev. 109, 532 (2019)

4. L. Murphy, N. Elimä, In Broad Daylight: Uyghur Forced Labour and Global Solar Supply Chains (2021)

5. Business \& Human Rights Resource Centre, Renewable Energy Renewable Energy \& Human Rights benchmark: Key Findings from the Wind \& Solar Sectors (2020)

6. N.M. Haegel, H. Atwater, T. Barnes, C. Breyer, A. Burrell, Y.-M. Chiang, S. de Wolf, B. Dimmler, D. Feldman, S. Glunz, J.C. Goldschmidt, D. Hochschild, R. Inzunza, I. Kaizuka, B. Kroposki, S. Kurtz, S. Leu, R. Margolis, K. Matsubara, A. Metz, W.K. Metzger, M. Morjaria, S. Niki, S. Nowak, I.M. Peters, S. Philipps, T. Reindl, A. Richter, D. Rose, K. Sakurai, R. Schlatmann, M. Shikano, W. Sinke, R. Sinton, B.J. Stanbery, M. Topic, W. Tumas, Y. Ueda, J. van de Lagemaat, P. Verlinden, M. Vetter, E. Warren, M. Werner, M. Yamaguchi, A.W. Bett, Science (New York, N.Y.) 364, $836(2019)$

7. A. Müller, L. Friedrich, C. Reichel, S. Herceg, M. Mittag, D.H. Neuhaus, Solar Energy Mater. Solar Cells 230, 111277 (2021)

8. EIT RawMaterials, ReProSolar: Demonstrator of High Grade PV Recovery Value Chain in Europe (2021), https://eitrawmaterials.eu/project/reprosolar/, accessed Aug 31, 2021

9. VDMA, International Technology Roadmap for Photovoltaic (ITRPV): 2020 Results. 2020 Results, No. 12. Edition, 2021
10. S. Herceg, M. Dick, E. Gervais, K.-A. Weiß, Conceptualized Data Structure for Sustainability Assessment of Energy and Material Flows: Example of a PV Life Cycle, in 4th PLATE 2021 Virtual Conference, 26-28 May (2021)

11. D. Schrijvers, A. Hool, G.A. Blengini, W.-Q. Chen, J. Dewulf, R. Eggert, L. van Ellen, R. Gauss, J. Goddin, K. Habib, C. Hagelüken, A. Hirohata, M. Hofmann-Amtenbrink, J. Kosmol, M. Le Gleuher, M. Grohol, A. Ku, M.-H. Lee, G. Liu, K. Nansai, P. Nuss, D. Peck, A. Reller, G. Sonnemann, L. Tercero, A. Thorenz, P.A. Wäger, Resources, Conserv. Recycl. 155, 104617 (2020)

12. E. Gervais, S. Herceg, S. Nold, K.A. Weiss, IEEE J. Photovolt. (accepted) (2021)

13. SolarPower Europe, Solar Sustainability Best Practices Benchmark (2021)

14. Solarcentury, Solar: A Force for Good: ESG Expectations for the Solar Sector. ESG Expectations for the Solar Sector, 2021

15. United Nations, Goal 12: Ensure sustainable consumption and production patterns, https://www.un.org/sustainable development/sustainable-consumption-production/, accessed Jun 29, 2021

16. G. Blengini, C. Latunussa, U. Eynard, C. Torres de Matos, D. Wittmer, K. Georgitzikis, C. Pavel, S. Carrara, L. Mancini, M. Unguru, D. Blagoeva, F. Mathieux, D. Pennington, Study on the EU's list of Critical Raw Materials (2020): Final Report (2020)

17. BMWi, Rohstoffstrategie der Bundesregierung: Sicherung einer nachhaltigen Rohstoffversorgung Deutschlands mit nicht-energetischen mineralischen Rohstoffen (2020)

18. S. Enkhardt, European PV organization requests $€ 20 \mathrm{bn}$ to support manufacturing, https://www.pv-magazine.com/ 2021/04/14/european-pv-organization-requests-e20bn-tosupport-manufacturing/, accessed Jun 29, 2021 (2021) 
19. The Association of European Renewable Energy Research Centers, EUREC public workshop: Strength through cooperation: Europe's PV value chain working together, (2021)

20. E. Gervais, S. Shammugam, L. Friedrich, T. Schlegl, Renew. Sustain. Energy Rev. 137, 110589 (2021)

21. M. Lokanc, R. Eggert, M. Redlinger, The Availability of Indium: Present, Medium Term, and Long Term (2015)

22. European Commission, Study on the EU's list of Critical Raw Materials: Factsheets on Critical Raw Materials (2020)

23. Federal Ministry of Agriculture, Regions and Tourism, World Mining Data 2020 (2020)

24. M. Frenzel, C. Mikolajczak, M.A. Reuter, J. Gutzmer, Resources Policy 52, 327 (2017)

25. D. Mulvaney, Solar Power (University of California Press, 2019)

26. Cradle to Cradle Products Innovation Institute (2021), https://www.c2ccertified.org/get-certified/product-certifica tion, accessed Oct 29, 2021

27. Green Electronics Council, EPEAT Criteria, https://green electronicscouncil.org/epeat-criteria/, accessed Oct 29, 2020

28. DVGW, Trinkwasserverordnung - Garant für sauberes Trinkwasser (2020), https://www.dvgw.de/themen/wasser/ trinkwasserverordnung, accessed Jun 30, 2021

29. European Comission, Commission Implementing Decision (EU) 2018/1147 of 10 August 2018 establishing best available techniques (BAT) conclusions for waste treatment, under Directive 2010/75/EU of the European Parliament and of the Council (2018)

30. J.A. Tsanakas, A. Heide, T. Radavičius, J. Denafas, E. Lemaire, K. Wang, J. Poortmans, E. Voroshazi, Prog. Photovolt. Res. Appl. 28, 454 (2020)

31. European Comission, Discussion paper on potential Ecodesign requirements and Energy Labelling scheme(s) for photovoltaic modules, inverters and systems (2021)

32. G. Eder, Y. Voronko, G. Oreski, W. Mühleisen, Possible repair strategies for PV-modules with cracked backsheets (2019)

33. VDI, VDI 4800 Part 2: Resource efficiency: evaluation of raw material demand. Evaluation of raw material demand (2018)

34. G. Dehoust, A. Manhart, P. Dolega, R. Vogt, C. Kemper, A. Auberger, F. Becker, C. Scholl, A. Rechlin, M. Priester, Environmental criticality of raw materials: an assessment of environmental hazard potentials of raw materials from mining and recommendations for an ecological raw materials policy. An assessment of environmental hazard potentials of raw materials from mining and recommendations for an ecological raw materials policy (2020)

35. E. Bellini, Silver accounts for $10 \%$ of PV module costs (2021), https://www.pv-magazine.com/2021/03/04/silver-currentlyaccounts-for-10-of-pv-module-costs/, accessed Jun 30, 2021

36. P. Stolz, R. Frischknecht, G. Heath, K. Komoto, J. Macknick, P. Sinha, A. Wader, Water Footprint of
European Rooftop Photovoltaic Electricity based on Regionalised Life Cycle Inventories: IEA PVPS Task 12, International Energy Agency Power Systems Programme, Report IEA-PVPS T12-11:2017 (2017)

37. M. Berger, J. Campos, M. Carolli, I. Dantas, S. Forin, E. Kosatica, A. Kramer, N. Mikosch, H. Nouri, A. Schlattmann, F. Schmidt, A. Schomberg, E. Semmling, Water Resour. Manag. 35, 1291 (2021)

38. European Comission, Product Environmental Footprint Category Rules (PEFCR): Photovoltaic modules used in photovoltaic power systems for electricity generation Version $1.2(2020)$

39. RE100, We are committed to $100 \%$ renewable power, https://www.there100.org/, accessed Oct 29, 2020

40. J.C. Goldschmidt, L. Wagner, R. Pietzcker, L. Friedrich, Energy Environ. Sci. 14, 5147 (2021)

41. L. Méndez, E. Forniés, D. Garrain, A. Pérez Vázquez, A. Souto, T. Vlasenko, Sci. Total Environ. 789, 147969 (2021)

42. J. Walzberg, A. Carpenter, G.A. Heath, Nat. Energy 6, 913 (2021)

43. International Council on Mining \& Metals, Improving Estimates of Releases from Mine Tailings in Life Cycle Assessment (2019), http://www.icmm.com/en-gb/events/ 2019/improving-estimates-of-releases-from-mine-tailings-inlife-cycle-assessment, accessed Jun 30, 2021

44. Deutsche Umwelthilfe, A white paper on strengthening the circularity of photovoltaics: Challenges and opportunities along the lifecycle. Challenges and opportunities along the lifecycle (2021)

45. N.J. Bartie, Y.L. Cobos-Becerra, M. Fröhling, R. Schlatmann, M.A. Reuter, Resour. Conserv. Recycl. 169, 105516 (2021)

46. L. Milios, Circ. Econ. Sust. 1, 477 (2021)

47. SEIA, Solar Industry Commitment to Environmental \& Social Responsibility: Participant Handbook (2021)

48. SEIA, Diversity Best Practices Guide for the Solar Industry (2019)

49. UNRISD, Measuring Corporate Sustainability: Towards accounting fit for the SDGs (2020)

50. CERA, The Certification of raw materials, https://www. cera-standard.org/, accessed Oct 29, 2020

51. S. Valdivia, J.G. Backes, M. Traverso, G. Sonnemann, S. Cucurachi, J.B. Guinée, T. Schaubroeck, M. Finkbeiner, N. Leroy-Parmentier, C. Ugaya, C. Peña, A. Zamagni, A. Inaba, M. Amaral, M. Berger, J. Dvarioniene, T. Vakhitova, C. Benoit-Norris, M. Prox, R. Foolmaun, M. Goedkoop, Int. J. Life Cycle Assess. 26, 1900 (2021)

52. B. Baue, Working Paper 2019-5: Compared to What? A Three-Tiered Typology of Sustainable Development Performance Indicators: From Incremental to Contextual to Transformational (2019)

Cite this article as: Estelle Gervais, Sina Herceg, Sebastian Nold, Karl-Anders Weiß, Sustainability strategies for PV: framework, status and needs, EPJ Photovoltaics 12, 5 (2021) 